\title{
咽喉頭炎により喘鳴症を呈した黑毛和種子牛の一例
}

\author{
佐々木 宏 ${ }^{1)}$ 渡辺大作 ${ }^{1)}$ 小松 咲 ${ }^{11}$ \\ 安藤貴朗 ${ }^{1)^{2}}$ 大塚浩通 ${ }^{1)}$ 及川正明 ${ }^{11}$ \\ ${ }^{1)}$ 北里大学獣医学部 \\ 2)酪農学園大学獣医学部
}

\section{A case of wheezing associated with pharyngolaryngitis in a Japanese Black calf}

\author{
H. Sasaki ${ }^{1)}$, D. Watanabe ${ }^{1)}$, S. Komatu ${ }^{1)}$, \\ T. Ando ${ }^{1 / 2)}, \mathrm{H}$. Ohtsuka ${ }^{1)}$ and M. Oikawa ${ }^{1)}$ \\ ${ }^{1)}$ School of Veterinary Medicine, Kitasato University \\ ${ }^{2}$ School of Veterinary Medicine, Rakuno Gakuen University
}

\begin{abstract}
要 約 14日齢から25日齢まで喘鳴症にて抗生物質と副腎皮質ホルモン剂により治療された31日齢 の黑毛和種の雌子牛が 再発により北里大学獣医学部付属動物病院に入院したロ入院時口吸気時の喘鳴 音【努力性呼吸、食欲不振および運動不耐性がみられたロ 内視鏡検査により咽喉頭粘膜の充血】左右被 裂軟骨の麻瘏および右側被裂軟骨の腫脹と内側への变位か認められロ咽喉頭炎と診断した口治療に用い

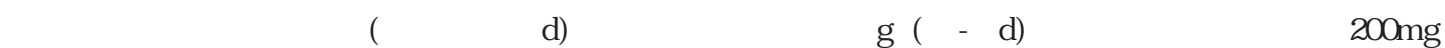
( 3-22d)【 リンコマイシン400mg ( 3-27d)【 タイロシン800mg (32-44d)【オキシテトラサイクリン400 mg (46-54d)であった口 抗炎症剂としてプレドニゾロン20mg( 1-5d), 10mg( 6-11d), $5 \mathrm{mg}(12-15 \mathrm{~d})$ の 筋肉注射 フルニキシン $140 \mathrm{mg}$ (16-22d) の静脈内投与を実施しロ カナマイシン250mgまたはゲンタマ イシン50mgと気管支拡張斉の噴霧吸入 ( 1 -10d 1422d) およびポビドンヨードの咽喉頭部塗布(32-54d) を行ったロ第 6 病日に喘鳴音の軽減と食欲が回復しロ 第16病日には採食時以外に喘鳴音が消失しロ 第54 病日に喘鳴音は消失し治癒したロ 以上より口咽喉頭炎による喘鳴症に対する抗生物質と抗炎症薬の長期 投与の有効性が示された口
\end{abstract}

——ーワード：子牛口喘鳴音口咽喉頭炎

家畜臨床誌３2(1):12-17, 2009

ABSTRACT A 31-day-old Japanese Black female calf was admitted to the Large A nimal T reatment Center of Kitasato University because her wheezing, which had been treated with antibiotics and corticosteroids from 14 to 25 days of age, had relapsed. Wheezing, labor ed respiration, anorexia and exercise intolerance were seen at the initial visit. Endoscopic examination showed hyperemia of the laryngopharynx mucosa, and bilateral arytenoid cartilage paralysis with the right arytenoid cartilage swollen and medially displaced. The calf was therefore diagnosed with

\footnotetext{
Received 10 December 2008/ A ccepted 10 February 2009

* Correspondence to: Daisaku Watanabe, Laboratory of Large A nimal Surgery, School of Veterinary Medicine, Kitasato University, 35-1, Higashi 23 Ban-cho, T ow ada, A omori 0348628 Japan ( ₹ 034-8628 青森県十和田市東23番町35-1 北里大学獣医学部獣医学科大動物外科学研究室) E-mailアドレス dwatanab@vmas.kitasato-u.ac.jp
} 
pharyngolaryngitis, and given the following treatment. The antibiotic used and daily dose (treatment period) were cefazolin $1 \mathrm{~g}$ (day 1-2), enrofloxacin $200 \mathrm{mg}$ (day 3-22), lincomycin $400 \mathrm{mg}$ (day 3-27), ty losin $800 \mathrm{mg}$ ( day 32-44), and oxy tetracycline $400 \mathrm{mg}$ (day 46-54). Prednisolone 20 mg (day 1-5), $10 \mathrm{mg}$ (day 6-11), $5 \mathrm{mg}$ (day 12-15) was administered by intramuscular injection, and flunixin $140 \mathrm{mg}$ (day 16-22) was administered by intravenous injection, as antiinflammatory drugs. Inhalation treatment with kanamycin $250 \mathrm{mg}$ or gentamicin $50 \mathrm{mg}$ and a bronchodilator was also performed. Povidone iodine was applied to the laryngopharynx. The wheezing and appetite improved by day 6 . By day 16, there was no wheezing except at feeding, and wheezing disappeared completely by day 54. These results suggest that long-term administration of antibiotics and antiinflammatory drugs is effective in treating wheezing caused by pharyngolary ngitis.

Key Words : Calf, Wheezing, Pharyngolaryngitis Jpn. J. V et. Clinics 32( 1):12-17, 2009

\section{緒 言}

呼吸時の喘鳴は主に上部気道の狭窄が原因で発生する [18]が口牛の喘鳴は咽喉頭炎口子牛ジフテリア症口喉頭 膿瘍、喉頭における浮腫口肉芽形成口乳頭腫症などの咽 喉頭の疾患でしばしば発症する[ 3，12, 20]ロ 米国コロ ラド州のフィードロット牛約 3 万頭に関すると畜場での 調査では口 ジフテリー性喉頭炎の発生が1.4\%ロ喉頭部に おける乳頭腫症の発生が4.4\%であったと報告されている [12] 細菌性の喉頭炎は抗生物質やサルファ斉による治 療で台癒するが病勢が進行し悪化しているものは弚れ に加えて副腎皮質ホルモン斉の投与を行なう［８］しか し口進行した喉頭炎では全身性の抗生物質および抗炎症 薬による治療は効果を示さないという報告もあり口关の 場合は外科的処置が推奨されている[ 3，5，7，10]ם

咽喉頭の観察は喉頭鏡や内視鏡により可能であり口確 定診断や炎症・狭窄の有無の診断に有用であるが口本邦 での報告はほとんどみられない[ 16, 21]ם

今回口重度の喘鳴症を呈し内視鏡検査により咽喉頭炎 と診断された黑毛和種子牛に遭遇しロ 長期の抗生物質と 抗炎症薬の投与およびポビドンヨードの咽喉頭部塗布に より治癒させることができたので報告するロ

\section{症 例}

来院前の臨床経過 : 症例は黑毛和種の雌子牛で 出生 後異常なく経過していたが 14日齢時に喘鳴音および肺 炎の症状を発症し口地元の獣医師によるアンピシリン $200 \mathrm{mg}$ とプレドニゾロン50mgによる治療を受け症状が 改善したため経過観察となった口しかしロ22日齢時に再 発し前述の治療を 3 日間続けて一旦回復したが 31日齢 時に再々発したため本大学大動物診療センターに入院し たロ

来院時の臨床症状 : 入院時の体重は61.5kgで口体温は $39.6^{\circ} \mathrm{C} \square$ 心拍数は112回/分口呼吸数は42回/分であったロ

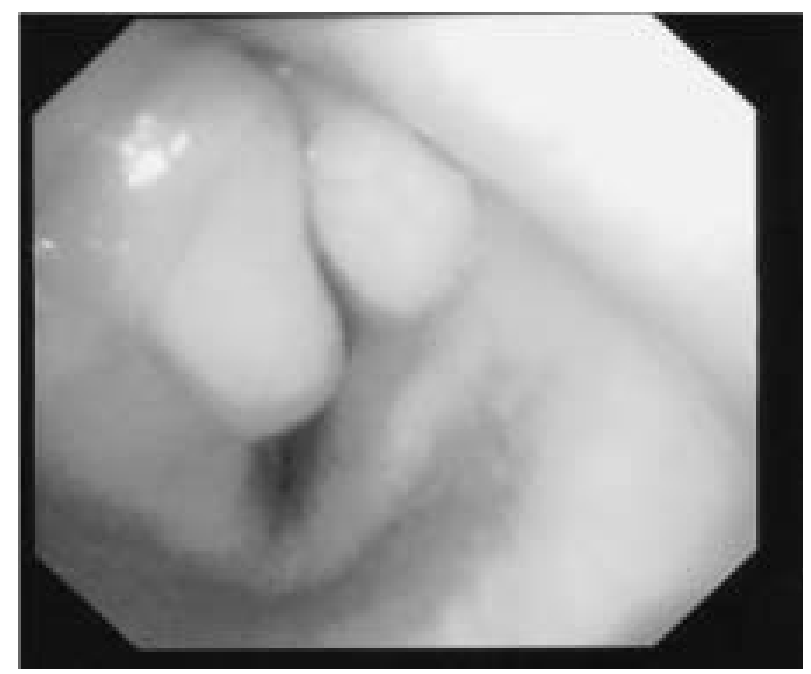

図1．来院時の内視鏡検査所見 咽喉頭粘膜の充血と右被裂軟骨の腫脹および内側へ の変位

吸気時に高調な喘鳴音と呼気時に低調ないびき音か聴取 されロ努力性の呼吸と乾性の発咳か認められた口触診に より喉頭部の腫大が確認され口同部の圧迫により発咳が 誘発されたロさらにロ 食欲廃絶し口長時間起立できない などの運動不耐性の所見がみられたロ内視鏡検査所見に おいてい咽喉頭粘膜の充血口右側被裂軟骨の腫脹および 左右被裂軟骨の麻㾝か認められ』また右側被裂軟骨は外 側から圧迫され内側に変位していた (図1)】

血液検查所見においてロ 白血球数 (WBC) が14,000／ $\mu \ell \square$ 分葉核好中球数 (Seg) が9,800/ $\mu$ と増加していた (表 1)!生化学検査では口 血漿Caが8.9mg/dI0 A/G比 が0.87とやや低值を示していた（表 2 )、血液ガス検査 所見においてロ 動脈血酸素分圧 $\left(\mathrm{PaO}_{2}\right)$ は $90 \mathrm{mmHg}$ 動脈血二酸化炭素分圧 $\left(\mathrm{PaCO}_{2}\right)$ は $39 \mathrm{mmHg}$ で正常 範囲内であった口

来院後の臨床経過 : 第1病日から第 2 病日までの治療 は口気管支拡張薬 (メプチンロ 大塚製薬口東京) $0.5 \mathrm{ml}$

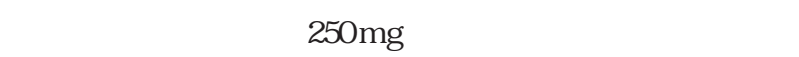




\begin{tabular}{cccccccc}
\hline & \multicolumn{7}{c}{ 病日 } \\
\hline \hline 項目 & & 1 & 4 & 7 & 12 & \multicolumn{1}{c}{26} & 47 \\
\hline \hline $\mathrm{RBC}$ & $\left(\times 10^{4} / \mu l\right)$ & 972 & 1,034 & 1,040 & 1,013 & 1,021 & 963 \\
$\mathrm{Hb}$ & $(\mathrm{g} / \mathrm{dl})$ & 9.2 & 9.7 & 9.9 & 9.7 & 10.7 & 10.1 \\
$\mathrm{Ht}$ & $(\%)$ & 28 & 29 & 29 & 29 & 32 & 29 \\
$\mathrm{WBC}$ & $\left(\times 10^{2} / \mu \ell\right)$ & 140 & 105 & 106 & 60 & 52 & 80 \\
Band & $(/ / \mu l)$ & 0 & 892 & 159 & 120 & 182 & 40 \\
Seg & $(/ / \mu l)$ & 9,800 & 6,090 & 5,777 & 3,180 & 988 & 2,440 \\
Lymp & $(/ / \mu l)$ & 3,010 & 3,307 & 3,339 & 2,070 & 3,484 & 4,800 \\
Mono & $(/ / \mu l)$ & 1,050 & 157 & 1,272 & 600 & 494 & 480 \\
Eosin & $(/ / \mu l)$ & 70 & 0 & 53 & 30 & 52 & 80 \\
Baso & $(/ / \mu l)$ & 70 & 0 & 0 & 0 & 0 & 0 \\
\hline
\end{tabular}

$\mathrm{RBC}$; 赤血球数 $\mathrm{Hb}$; ヘモグロビン $\mathrm{Ht}$; ヘマトクリット值 $\mathrm{WBC}$; 白血球数 $\mathrm{B}$ ～ $\mathrm{Bnd}$; 桿状核好中球

Seg ; 分葉核好中球口 Lymp ; リンパ球 Mono ; 単球 E E osin ; 好酸球口Baso ; 好塩基球

表2．血液生化学所見

\begin{tabular}{cccccccc}
\hline & \multicolumn{7}{c}{ 病日 } \\
\hline \hline 項目 & & 1 & 4 & 7 & 12 & 26 & 47 \\
\hline TP & $(\mathrm{g} / \mathrm{dl})$ & 7.1 & 7.4 & 7.2 & 7.1 & 6.5 & 6.5 \\
A LB & $(\mathrm{g} / \mathrm{dl})$ & 3.3 & 3.4 & 3.4 & 3.4 & 3.2 & 3.3 \\
A /G & & 0.87 & 0.85 & 0.89 & 0.92 & 0.97 & 1.03 \\
Glu & $(\mathrm{mg} / \mathrm{dl})$ & 75 & 88 & 84 & 76 & 79 & 87 \\
T .chol & $(\mathrm{mg} / \mathrm{dl})$ & 135 & 146 & 142 & 127 & 108 & 107 \\
A ST & $(\mathrm{IU} / \mathrm{l})$ & 63 & 114 & 139 & 73 & 59 & 64 \\
GGT & $(\mathrm{IU} / \mathrm{l})$ & 23 & 24 & 24 & 22 & 15 & 15 \\
LDH & $(\mathrm{IU} / \ell)$ & 757 & 1,001 & 1,191 & 1,078 & 917 & 985 \\
CPK & $(\mathrm{IU} / \ell)$ & 334 & 780 & 2,110 & 386 & 245 & 513 \\
UN & $(\mathrm{mg} / \mathrm{dl})$ & 11.3 & 9.1 & 10.3 & 13.2 & 10.2 & 12 \\
Crea & $(\mathrm{mg} / \mathrm{dl})$ & 0.91 & 0.71 & 0.88 & 0.86 & 0.79 & 0.10 \\
iP & $(\mathrm{mg} / \mathrm{dl})$ & 6.0 & 6.2 & 6.9 & 7.4 & 9.0 & 8.3 \\
Ca & $(\mathrm{mg} / \mathrm{dl})$ & 8.9 & 9.3 & 9.8 & 9.8 & 10.7 & 10.3 \\
Mg & $(\mathrm{mg} / \mathrm{dl})$ & 1.1 & 1.7 & 2.1 & 2.2 & 2.0 & 2.0 \\
\hline
\end{tabular}

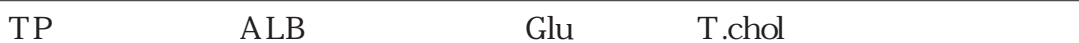

A ST ; アスパラギン酸アミノトランスフェラーゼロ GGT ; y -グルタミルトランスフェラーゼロ

$\mathrm{LDH}$; 乳酸脱水素酵素 $\mathrm{CPK}$; クレアチンフォスフォキチーゼ

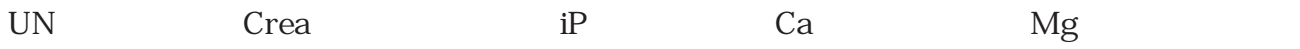

表3．薬剂感受性試験の結果

\begin{tabular}{cccccccccc}
\hline ENR & OBFX & CEZ & A BPC & PC & KM & SM & TC & GM \\
\hline+++ & +++ & ++ & - & - & - & + & - & + \\
\hline
\end{tabular}

E.coliを用いた感受性試験

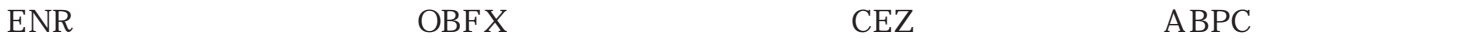

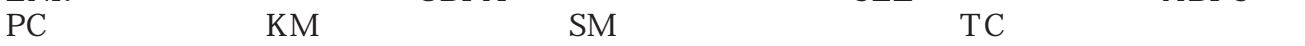

GM : ゲンタマイシン

を1日1回行なうとともにロ セファゾリン1gおよび副 腎皮質ホルモン剂(プレドニゾロン) $5 \mathrm{mg}$ 筋肉注射 を1日 2 回行なった口第 2 病日より乾草を少量食べ始め たが 配合飼料 (カーフスターターロ雪印 茨城) は食べ なかったロ またロ ミルク $100 \mathrm{~g} / 1$ l を一日 3 回給与した口

鼻汁の細菌培養検査の結果Ｅscherichia coliと Staphylococcus chromogenes が分離同定され口E.coli を用いたディスク法による薬剤感受性試験ではエンロフ ロキサシンおよびオルビフロキサシンに高い感受性がみ
られた (表 3 ) 】薬剂感受性試験の結果を受けて第 3 病 日より抗生物質を变更し口吸入治療の抗生物質をゲンタ マイシン50mgにロ またセファゾリンを中止しロ 1 日 2 回ずつエンロフロキサシン100mg 塩酸リンコマイシン $200 \mathrm{mg}$ およびプレドニゾロン $10 \mathrm{mg}$ の筋肉注射を開始し た口第 5 病日より努力性呼吸が軽度になり口 乾草の採食 量も増え口配合飼料を食べ始めた口第 6 病日に喘鳴音が 聴取される頻度が減少したためロプレドニゾロンの1回 投与量を $5 \mathrm{mg}$ に減じた口第 8 病日より気管支拡張薬の 


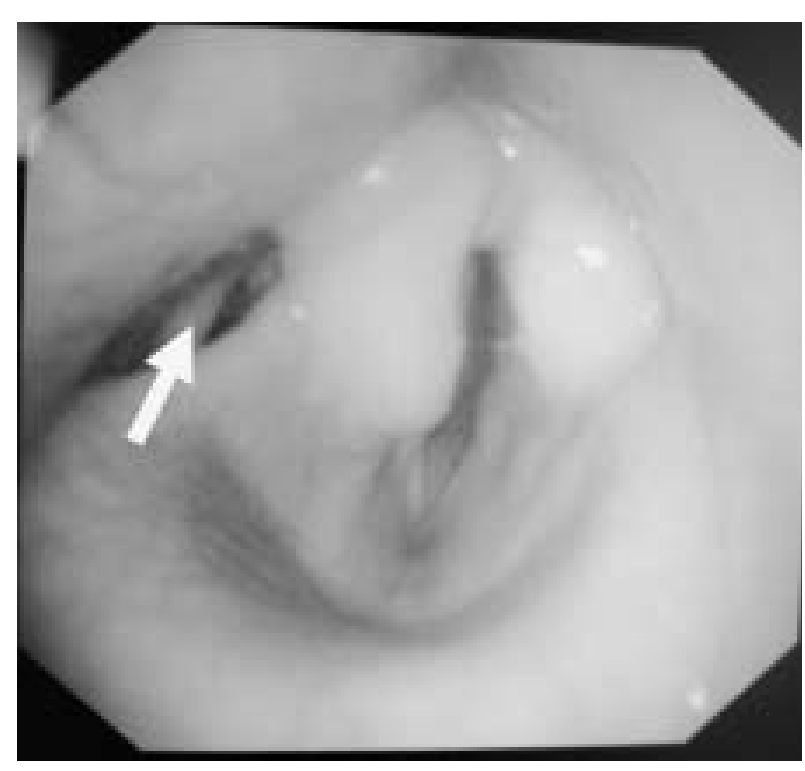

図2，第32病日の内視鏡検査所見

被裂軟骨の腫脹は軽減したが、右側被裂軟骨と咽頭 粘膜壁の間の凹みに白色膿様物と食塊がみられた ( 矢印)

吸入を中止し口同日より安静時の喘鳴音は小さくなった が採食時および飲水時は依然喘鳴音か聴取された口第 9病日より口 乾草およびスターターを完食するようになっ たロ第11病日より喘鳴音の頻度がさらに減少したため吸 入治療を中止し口第12病日よりプレドニゾロンの1回投 与量を $2.5 \mathrm{mg}$ に減じた口第12病日における血液検査所見

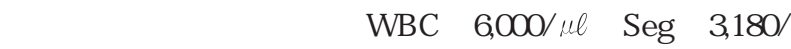
uとと減少し口A/G比が0.92と増加していた（表1)】第 14病日より喘鳴音か聴取される頻度が増加したため抗 生物質としてゲンタマイシン50mgを用いた吸入治療を 再び実施したロ 第16病日より安静時において喘鳴音は聴 取されなくなり口呼気時のいびき音の頻度も隇少したが 採食時および飲水時は依然明瞭な喘鳴音が聴取されたロ またロ 同日よりプレドニゾロンをフルニキシンメグルミ ン (フルニキシンとして $140 \mathrm{mg} /$ 日) の静脈内投与に変 更した口第23病日より呼気時のいびき音が聴取されなく なったのでリンコマイシン以外の投薬を中止口第28病日 に全ての投薬を中止し経過を観察したロ

第32病日に再び内視鏡検査を行い口咽喉頭粘膜の充血口 右側被裂軟骨の腫脹と内側変位および両側被裂軟骨の麻 㾝などの改善が認められた(图 2)】また口右側被裂軟骨 と咽頭粘膜壁の間に形成された凹みに白色膿樣物と食塊 が確認されたロ 依然としてロ 軽度ではあるが採食時の 喘鳴が続いたためロ第32病日よりタイロシン $800 \mathrm{mg} /$ 日 の筋肉注射および朝夕 2 回 $0.5 \%$ ポビドンヨード (のどぬー るスプレーロ 小林製薬 大阪) の口腔内投与を開始したロ 0.5\%ポビドンヨードは製品のノズルを口腔内に挿入して
咽喉頭部に 6 回噴射した口採食時の喘鳴は軽減したが消 失しなかったためロ 第46病日よりタイロシンに変えて塩 酸オキシテトラサイクリン(OTC) $400 \mathrm{mg}$ 筋肉注射を 開始した口第54病日には採食時の喘鳴音か聴取されなく なったので全ての投薬を中止しロ 第56病日に退院した口 退院後 5 ヶ月を経過した時点で再発はみられていない口

\section{考 察}

本症例は呼吸時の喘鳴音と口内視鏡検査における咽喉 頭粘膜の充血口被裂軟骨の腫脹口麻痺ならびに内側变位 から咽喉頭炎と診断された口子牛の喘鳴症は咽喉頭の疾 患による喉頭部の狭窄によりしばしば発生する[ 3，5， $7,10,22] \square$ 本症例においても内視鏡検査所見より口喉 頭部の炎症による狭窄が原因て喘鳴症が発症したものと 考えられた口

牛の咽頭炎および喉頭炎は若龄牛に比較的多く [ 3, 5, $7,8,10]$ 感染性疾患および機械的刺激等から発し口 罹患すると呼吸困難口喘鳴口食欲不振などの症状がみら れる[ 8, 10, 20]ם 喉頭炎は他の呼吸器疾患に併発する ことが多く[20]ם本症例では来院前に肺炎の治療を受け ていたことからロ肺炎からの併発か推察された口

牛の喉頭炎ではFusobacterium necrophorum 【 Corynebacterium pyogenes! Histophilus somni およ びPasteurella 属菌などの分離例が多い[ 8，12, 20] が口 本症例では鼻汁培養により Escherichia coli と Staphylococcus chromogenesが分離同定された は新生子牛の下痢症などの起因菌として知られ [15] S.chromogenes は乳牛の乳房炎口 羊の皮膚病および豚 の滲出性皮膚炎の原因菌として知られている[ 1，2，4] S.chromogenes は多くの抗生物質に感受性であるが口 ペニシリナーゼ産生株やリンコマイシン耐性株の存在も 報告されている[4][一方口咽喉頭炎の牛の内側咽頭後 リンパ節からE.coli と Proteus mirabilisが分離されたと の報告もある[21] 本症例ではE.coli の薬剂感受性試験 結果を踏まえた抗生物質の投与を実施した口

進行した喉頭炎は合成抗生物質や消炎剂による治療に 反応しないとされているが[ 3，10]ם Plenderleith [17] は喉頭膿瘍の子牛に対してリンコマイシン $2.5-10 \mathrm{mg} / \mathrm{kg}$ の長期投与が有効であったと報告しており口 Milneら [ 14] は慢性喉頭軟骨炎の子牛にステロイドとリンコマイ シンを併用した治療が有効であったと報告しているロ ま た慢性喉頭炎口喉頭軟骨炎およびジフテリ一性壊死性喉 頭炎等では病巣の外科的除去および喉頭切開術が一定の 成功をおさめているが 治療期間が長くかかることロ気 
管支の狭窄や粘膜の過形成等の後遺症の発生口喉頭切開 部が約 $90 \%$ 症例で閉鎖しないなどの問題も指摘されて いる[ 3，5，7，10,14]】このためם 本症例では初期か らリンコマイシンとプレドニゾロンを用い治療を行なっ たが採食時や飲水時に頸部を伸展させると喘鳴音が聴 取される状況が続いたためロ 長期にわたる抗生斉と消炎 斉の治療が必要と考えられたロ

本症例では口消炎剂としてまず低用量の副腎皮質ホル モン剂を投与したロ一般に副腎皮質ホルモン剂は炎症に よって生じる過度の疼痛や腫脹および機能障害を改善す る目的などで使用される[ 9]0 また敗血症の子牛に対し て $1.1 \mathrm{mg} / \mathrm{kg}$ のプレドニゾロンを投与したとの報告があ る[ 19] が口 臨床的には0.05-0.2mg/kgで十分な効果を示 すことが多い[14, 16] 本症例では第 3 病日から第 5 病 日まで0.33mg/kgロ第 6 病日から第11病日まで0.17 mg/ $\mathrm{kg}$ 第12病日から第15病日まで0.08mg/kgという低用量 で投与したロ副腎皮質ホルモン剂は高用量もしくは反復 投与を行なうと感染症の悪化や誘発感染症の発症の危険 性があり口 また連用後の急な投薬中止はホルモンバラン スを乱し副腎皮質機能不全か現れるとされている[ 9]が 仲佐ら [16] は咽頭炎の子牛に対して抗生物質とともに低 用量のデキサメサゾンを使用しロ副作用は認められなかっ たと報告しているい 本症例では投与期間中の副作用によ る症状の悪化は認められずロ 良好な経過を辿ることが出 来た口このことから口副腎皮質ホルモン刘の低用量・長 期投与は口 慢性化した咽喉頭炎に関しては有効な゙治療と なることが示唆されたロ

本症例では治療により比較的早期に安静時の喘鳴が消 失したが弚の後も採食時には喘鳴が聴取されたここれ は喉頭周囲の炎症が完全に治癒せず頸部の進展により右 被裂軟骨が内反した結果と考えられ】光れまでの経過か ら抗生物質による治療だけでは回復が困難と考えられた口 そこで 人で用いられる0.5\%ポビドンヨードの咽喉頭部 塗布と抗菌スペクトルの広いOTCによる治療を行なっ たところロ喘鳴は完全に消失し治癒した口ポビドンヨー ドは多くの細菌とウイルスに有効であり口皮膚表面の消 毒だけでなく～刺激性が少ないことから粘膜や創面にも 直接使用されている[11, 13] OTCはテトラサイクリン 系抗生物質であり口 グラム陽性菌および陰性菌口マイコ プラズマロ クラミジアロ リケッチアなどに有効で広い抗 菌スペクトルを持つ抗生物質として臨床的に広く利用さ れている[ 6]が口本症例では鼻腔ぬぐい液から採取され たE.coliの薬斉感受性試験においてOT Cは感受性が低かっ たことから使用していなかった口このことから口咽喉頭
炎の起因菌と鼻腔から採取された菌が異なっていた可能 性が考えられたロ

これらの結果からロ抗生物質と抗炎症薬の長期投与は 喘鳴症を伴う重度の咽喉頭炎に対して有効であることが 示唆されたが口 抗生物質の適切な選択と投与期間および ポビドンヨードの咽喉頭部塗布の効果については症例を 重ねて検討したいロ

\section{参考文献}

1. A nderson LO, A hrens P, Daugaard L and BilleHansen V (2005) Exudative epidermitis in pigs caused by toxigenic Staphylococcus chromogenes. V et. Miclobiol. 105 : 291-300

2. A ndrews A H and Lamport A (1997) I solation of Staphylococcus chromogenes from an unusual case of impetigo in goat. V et. Rec. $140: 584$

3. De Moor A and Vershooten F (1968) Surgical treatment of laryngeal roaring in calves. $V$ et. Rec. $83: 262-264$

4. Devriese LA, Baele M, V aneechoutte M, Martel $A$ and Haesebrouck F (2002) Identification and antimicrobial susceptibility of Stapylococcus chromogenes isolates from intramammary infections of dairy cows. Vet. Microbiol. $87: 175-182$

5. Gasthuys F, Vershooten F, Parmentier D, De Moor A and Steenhaut M (1992) Laryngotomy as a treatment for chronic laryngeal obstruction in cattle: a review of 130 cases. $V$ et. Rec. $130: 220-223$

6. 五島瑳智子, 西田 実 (1984) 各種抗生物質の今後の 発展( 4) テトラサイクリン系薬剂. 日本臨床, $42: 547$

7. Goulding R, Schumacher J, Barrett DC and Fitzpatrick JL (2003) Use of a permanent tracheostomy to treat laryngeal chondritis and stenosis in heifer. V et. Rec. $152:$ 809-811

8. 橋本 晃 (2002) 主要症状を基礎にした牛の臨床. 172-174, デーリイマン, 札幌

9. 吐山豊秋 (1981) 副腎皮質ホルモンについて. 家 畜診療 $212: 3-10$

10. Heppelmann M, Rehage J and Sterke A (2007) Diphtheroid necrotic laryngitis in three calvesdiagnostic procedure, therapy and post-operative development. J. V et. Med. 54 : 390-392

11. 平田清秀, 植田候平, 名取穣治, 秀嶋周, 岩瀬和泉 (1989) ポピドンヨード液(ネオヨジン (R) 液)の手術 
部位消毒効果の検討. 基礎と臨床, 24 : 6451-6454

12. Jensen R, Lauerman LH, England JJ, Braddy PM, Horton DP, Flack DE, Cox MF, Einertson N, Miller GK and Rehfeld CE (1981) Laryngeal diphtheria and papillomatosis in feedlot cattle. V et. Pathol. 18 : 143-150

13. 鴨井久一, 宮田裕之, 扇正一, 清水智幸, 小出和良, 中島茂, 小島武志, 西澤聡, 東堤稔, 坂本雅子,

土屋利政, 波多江新平 (1990) 口腔内病原性細菌に対 するin vitroでのポピドンヨード溶液の殺菌効果. 日 歯周誌 32 : 660-666

14. Milne HM, Barrett DC, Sullivan $M$ and Fitzpatrick LJ (2000) Successful medical treatment of laryngeal chondritis in cattle. V et. Rec. $147: 305$ 306

15. Myers LL (1975) Characterization of Escherichia coli obtained from newborn calves with diarrhea. Infect. Immun. 11 : 493-496

16. 仲佐友身, 安中篤史, 羽瀬水奈子, 安藤貴朗, 大塚浩 通, 渡辺大作 (2006) 抗生物質と副腎皮質ホルモン刘 の併用処置により治癒した子牛の咽頭炎の一例. 家畜 臨床誌29 : 25-28

17. Plenderleith RWJ (1988) Treatment of cattle, sheep and horses with lincomycin: case studies. Vet. Rec. $122: 112-113$

18. Radostits OM, Blood DC and Gay CC (2007) Veterinary Medicine, 10th edition. 471-541

19. Semrad SD (1993) Comparison of flunixin, prednisolone, dimethyl sulfoxide, and a lazaroid ( U 74389F) for treating endotoxemic neonatal calves. A m. J. V et. Res. 59 : 1517-1522

20. Smith JA and Baker JC (1996) Large A nimal Internal Medicine. 2nd ed. (editor, Smith PB) 625 631. Mosby-Y ear Book, St. Louis

21. 渡辺大作, 安藤貴朗, 大塚浩通, 岡田らん, 朴天鎬, 小山田敏文 (2008) 咽喉頭炎により嚥下障害を呈した 黑毛和種子牛の一例. 日家臨感染誌.3(1) : 45-50

22. West HJ (1997) T racheolaryngostomy as a treatment for laryngeal obstruction in cattle. Vet. J. $153: 81-86$ 